\title{
WINTER 2010
}

\section{The}
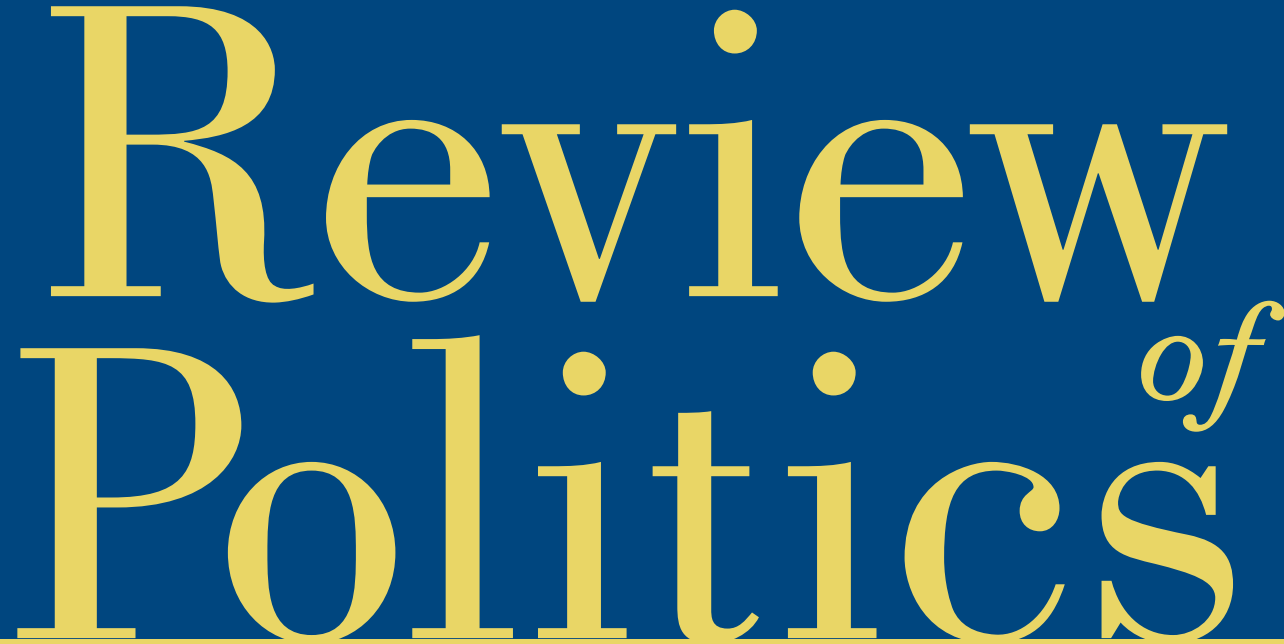

ARTICLES

Robert S. Taylor, "Kant's Political Religion: The Transparency of Perpetual Peace and the Highest Good"

Brandon P. Turner, "John Stuart Mill and the Antagonistic

Foundation of Liberal Politics"

Paul E. Kirkland, "Nietzsche's Tragic Realism"

Dean C. Hammer and Michael Kicey, "Simone Weil's Iliad:

The Power of Words"

James Gordon Finlayson, "Bare Life' and Politics in Agamben's

Reading of Aristotle"

Review Essay: Ralph Lerner, "Northern Lights Over Tocqueville" 


\title{
THE REVIEW OF POLITICS
}

\author{
Editor \\ CATHERINE H. ZUCKERT \\ Executive Associate Editor \\ DENNIS WM MORAN \\ Book Review Editor \\ PETER R. MOODY, JR. \\ Assistant Editor \\ LES HARRIS \\ Editorial Interns: \\ Joshua M. Bandoch \\ Andrew W. Bramsen \\ Associate Editors
}

Fred Dallmayr

E.A. Goerner

A. James McAdams

Ruth M. Abbey

Daniel Philpott

James Turner

Former Editors

Waldemar Gurian

M.A. Fitzsimons

Thomas Stritch

Frederick J. Crosson

Donald P. Kommers

Walter Nicgorski

Editorial Advisory Board

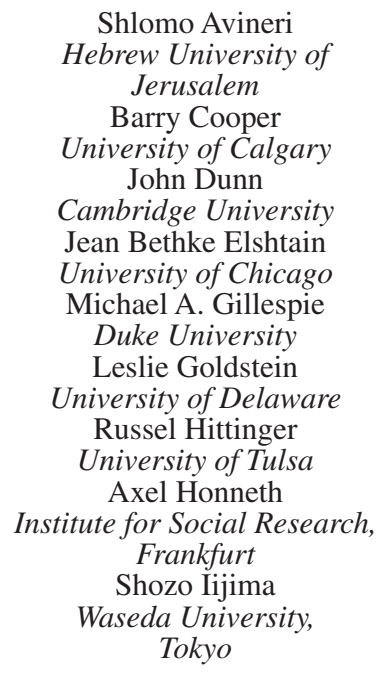

Ramin Jahanbegloo

University of Toronto Pierre Manent

L'Ecole des Hautes Etudes en sciences sociales

Harvey C. Mansfield

Harvard University Mary Nichols Baylor University

Bruce M. Russett Yale University

Arlene Saxonhouse

University of Michigan

Steven B. Smith

Yale University

Peter Steinberger

Reed College

John Witte, Jr.

Emory University

Jean M. Yarbrough

Bowdoin College

Administrative Assistant: Kelli Brown

The Review of Politics publishes primarily philosophical and historical studies of politics, especially those concentrating on political theory and American political thought. The journal also includes thoughtful scholarly reflections on all aspects of politics-including analysis of institutions and techniques, international relations, comparative politics, literary reflections on politics or political interpretations of literary works, constitutional theory and practices. 


\section{TABLE OF CONTENTS WINTER 2010}

Vol. 72

WINTER 2010

No. 1

Robert S. Taylor

Kant's Political Religion: The Transparency of

Perpetual Peace and the Highest Good

Brandon P. Turner

John Stuart Mill and the Antagonistic Foundation

of Liberal Politics . . . . . . . . . . . . . . . . . . . . . . . 25

Paul E. Kirkland

Nietzsche's Tragic Realism . . . . . . . . . . . . . 55

Dean C. Hammer and Michael Kicey

Simone Weil's Iliad: The Power of Words . . . . . . . . . . 79

James Gordon Finlayson

"Bare Life" and Politics in Agamben's Reading

of Aristotle

Review Essay:

Ralph Lerner

Northern Lights Over Tocqueville

Reviews:

George Thomas: COMMERCE OF IDEAS IN THE EXTENDED REPUBLIC

Review of Colleen A. Sheehan's James Madison and the Spirit of Republican Self-Government. . . . . . . . . . . . . . 141

Paul O. Carrese: WASHINGTON AS THINKER, AND HARMONIZER OF TRADITIONS

Review of Jeffry H. Morrison's The Political Philosophy of George Washington . . . . . . . . . . . . . . . . . . . . . 143

Eric MacGilvray: RORTY'S SELF-CONCEPTS

Review of Neil Gross's Richard Rorty: The Making of an American Philosopher. . . . . . . . . . . . . . . . . . . . 147

Aurelian Craiutu: THE RETURN OF CONSTANT

Review of Helena Rosenblatt's Liberal Values: Benjamin

Constant and the Politics of Religion . . . . . . . . . . . 150 
Jason Peters: THE NATURAL IN THE LIGHT OF THE SUPERNATURAL

Review of Matthew Dickerson and David O'Hara's

Narnia and the Fields of Arbol: The Environmental

Vision of C.S. Lewis . . . . . . . . . . . . . . . . . . . . 152

Mark D. Brewer: RELIGIOUS ACTIVISM AND

POLITICAL CIVILITY

Review of Jon A. Shields's The Democratic Virtues

of the Christian Right . . . . . . . . . . . . . . . . . . . 155

Andrey Kordochkin: FILLING THE GAP

Review of John and Carol Garrard's Russian Orthodoxy

Resurgent: Faith and Power in the New Russia . . . . . . . . . 157

Annika Marlen Hinze: MULTIVALENT

SIGNIFICANCES

Review of Bronwyn Winter's Hijab and the Republic:

Uncovering the French Headscarf Debate . . . . . . . . . . . . 159

Theresa Earenfight: THE EMERGENCE OF THE STATE

Review of Thomas N. Bisson's The Crisis of the Twelfth

Century: Power, Lordship, and the Origins of European

Government . . . . . . . . . . . . . . . . . . . . . 162

Alexander Green: BETWEEN HISTORY, PHILOSOPHY,

AND THE JEWISH TRADITION

Review of Joel Kraemer's Maimonides: The Life and

World of One of Civilization's Greatest Minds . . . . . . . . . . 164

Matthew D. Mendham: SYMPATHY FOR SOCIAL

JUSTICE

Review of Sharon R. Krause's Civil Passions:

Moral Sentiment and Democratic Deliberation . . . . . . . . 167

Kenneth C. Blanchard Jr.: IMPOSSIBLE KNOWLEDGE, TRUE OPINION

Review of Roslyn Weiss's Virtue in the Cave:

Moral Inquiry in Plato's Meno . . . . . . . . . . . . . . . . . . 170

Ryan K. Balot: DEMOCRACY'S SELF-QUESTIONING

Review of Gerald M. Mara's The Civic Conversations of

Thucydides and Plato: Classical Political Philosophy and the Limits of Democracy . . . . . . . . . . . . . . . . . . . 172

Kent Worcester: LESS REVOLUTIONARY THAN IT SEEMS

Review of Richard Davis's Typing Politics: The Role of Blogs in American Politics and Matthew Hindman's The Myth of Digital Democracy. . . . . . . . . . . . . . . . 175 
Sunila S. Kale: INDIA'S POLITICS AND FOREIGN POLICY

Review of Harsh V. Pant's Contemporary Debates in Indian Foreign and Security Policy: India Negotiates Its Rise in the International System . . . . . . . . . . . . . . . . . . 178

Emily M. Hill: A FULL PORTRAIT

Review of Jay Taylor's The Generalissimo: Chiang

Kai-shek and the Struggle for Modern China ............ 180 


\section{CONTRIBUTORS TO THIS ISSUE}

ROBERT S. TAYLOR is Assistant Professor of Political Science at the University of California, Davis. BRANDON P. TURNER is Assistant Professor of Political Science at Clemson University. PAUL E. KIRKLAND is Assistant Professor of Great Ideas and Political Science at Carthage College. DEAN C. HAMMER is The John W. Wetzel Professor of Classics and Professor of Government at Franklin and Marshall College. MICHAEL KICEY is a postdoctoral candidate in the Department of Comparative Literature at the University of Michigan. JAMES GORDON FINLAYSON is Senior Lecturer in Philosophy at the University of Sussex.

RALPH LERNER is Benjamin Franklin Professor Emeritus in the College of Social Thought at the University of Chicago. GEORGE THOMAS is Associate Professor of Government at Claremont McKenna College. PAUL O. CARRESE is Professor of Political Science at the United States Air Force Academy. ERIC MACGILVRAY is Assistant Professor of Political Science at the Ohio State University. AURELIAN CRAIUTU is Associate Professor of Political Science at Indiana University. JASON PETERS is Professor of English at Augustana College. MARK D. BREWER is Associate Professor of Political Science at the University of Maine. ANDREY KORDOCHKIN is the Dean of the Nativity of Christ Parish in Madrid, Spain. ANNIKA MARLEN HINZE is a doctoral candidate at the University of Illinois at Chicago in the Department of Political Science. THERESA EARENFIGHT is Associate Professor of History at Seattle University. ALEXANDER GREEN is a doctoral candidate at the University of Toronto in the Department of Religion and the Centre for Jewish Studies. MATTHEW D. MENDHAM is a doctoral candidate at the University of Notre Dame in the Department of Political Science. KENNETH C. BLANCHARD JR. is Professor of Political Science and Philosophy at Northern State University. RYAN K. BALOT is Associate Professor of Political Science at the University of Toronto. KENT WORCESTER is Associate Professor of 
Political Science and International Studies at Marymount Manhattan College. SUNILA S. KALE is Assistant Professor at Jackson School of International Studies, University of Washington. EMILY M. HILL is Associate Professor in the Department of History at Queen's University, Ontario, Canada. 
Subscription Information: The Review of Politics (ISSN 0034-6705) is published quarterly in February, May, August and November by Cambridge University Press, 32 Avenue of the Americas, New York, NY 10013-2473 USA/The Edinburgh Building, Shaftesbury Road, Cambridge CB2 8RU, UK for the University of Notre Dame. Annual subscription rates for Volume 72 (2010): Institutional subscription rates, print and online: US $\$ 120.00$ in the USA, Canada, and Mexico; UK $£ 68.00+$ VAT elsewhere. Institutional subscription rates, online only: US \$109.00 in the USA, Canada, and Mexico; UK $£ 58.00$ + VAT elsewhere. Institutional subscription rates, print only: US $\$ 115.00$ in the USA, Canada, and Mexico; UK $£ 62.00+$ VAT elsewhere. Individual subscription rates, print only: US $\$ 36.00$ in the USA, Canada, and Mexico; UK $£ 18.00+$ VAT elsewhere. Correspondence concerning subscriptions should be sent to: Cambridge University Press, 100 Brook Hill Drive, West Nyack, NY 10994, USA for customers in the USA, Canada, or Mexico. Customers elsewhere should contact: Cambridge University Press, The Edinburgh Building, Shaftesbury Road, Cambridge CB2 8RU, UK.

Editorial Office: All correspondence concerning submissions and manuscripts under review should be sent to The Review of Politics, University of Notre Dame, 547 Flanner Hall, Notre Dame, IN 46556. Phone: 574-631-6623. Email: ROP.Editor.1@nd.edu. Website: www.nd.edu/ rop

Abstracting and Indexing Information: Articles in The Review of Politics are indexed in the International Index to Periodicals and the Catholic Periodicals and Literature Index; abstracted in the International Political Science Abstracts; and abstracted and indexed in ABC POL. SCI., Historical Abstracts, Social Science Index (also available in the electronic versions), Book Review Index, and International Bibliography of the Social Sciences.

Copyright (C) 2010 University of Notre Dame. All rights reserved. No part of this publication may be reproduced, in any form or by any means, electronic, photocopy, or otherwise, without permission in writing from Cambridge University Press, Rights and Permissions Manager, 32 Avenue of the Americas, New York, NY 10013-2473 USA. For further information see http://us.cambridge/org/information/rights/.

Periodicals postage paid in New York, NY and additional mailing offices. Postmaster: Send address changes to The Review of Politics, Cambridge University Press, 100 Brook Hill Drive, West Nyack, NY 10994-2133 USA.

Photocopying information for users in the U.S.A.: the Item-Fee Code for the publication (0034-6705/10 \$9.00 +.10) indicates that copying for internal or personal use beyond that permitted by Sec. 107 or 108 of the U.S. Copyright Law is authorized for users duly registered with the Copyright Clearance Center (CCC) provided that the appropriate remittance of $\$ 9.00$ per article is paid directly to CCC, 222 Rosewood Drive, Danvers, MA 01923. Specific written permission must be obtained for all other copying. 